\title{
Preoperative Use of $0.2 \%$ Chlorhexidine Digluconate Mouthwash does not affect the Bacteremia following Closed Dental Extraction
}

\author{
Galina Gavazova $^{1}$, Eli Hristozova ${ }^{2}$, StanimirKisselov ${ }^{1}$, RalitsaRaycheva ${ }^{3}$, Nikolai Pavlov ${ }^{4}$, Petia \\ Pechalova $^{1 *}$ \\ ${ }^{1}$ Department of Oral surgery, Faculty of Dental medicine, Medical University, Plovdiv, Bulgaria \\ ${ }^{2}$ Department of Microbiology and Immunology, Faculty of Pharmacology, Medical University, Plovdiv, \\ Bulgaria \\ ${ }^{3}$ Department of Social medicine and community health, Faculty of community health, Medical University, \\ Plovdiv, Bulgaria \\ ${ }^{4}$ Private practice of oral surgery, Plovdiv, Bulgaria
}

*Corresponding Author: Petia Pechalova, Department of Oral surgery, Faculty of Dental medicine, Medical University, Plovdiv, Bulgaria, Email: pechalova@abv.bg

\begin{abstract}
Post extraction bacteremia is transitory condition observed in healthy individuals. Aim of the study at hand is to investigate the effect of preoperative rinsing of the mouth with $0.2 \%$ chlorhexidine digluconate on post extraction bacteremia following closed tooth extraction.
\end{abstract}

Materials and Methods: This research focused on evidence of bacteremia among 58 individuals, divided equally in two study groups - without preoperative rinsing (first group) and with preoperative rinsing (second group) with Parodontax Extra (GlaxoSmithKline, Great Britain), followed by open extraction of a single tooth. Aerobic and anaerobic hemocultures (Bact/ALERT, BioMerieux, Inc., Durham, N.C.) were used to establish the bacteremia, while blood samples were obtained preoperatively, 30 seconds after and 15 minutes after the extraction was completed.

Results: Preoperative bacteremia was established in 7 (12.07\%) patients in total - 4 patients from the first and 3 patients from the second group. At the $30^{\text {th }}$ second after the extraction was done bacteremia was established in $6(20.69 \%)$ patients from the first and in $8(27.59 \%)$ patients from the second group. At the $15^{\text {th }}$ minute mark bacteremia was found in 3 patients (10.34\%) from each group. We failed to identify any statistically significant difference in occurrence of bacteriemia among the subjects in both groups 30 seconds $(p=0.548)$ as well as 15 minutes after the extraction was completed $(p>0.05)$.

Conclusions: Rinsing the mouth with $0.2 \%$ chlorhexidine digluconate mouthwash does not appear to offer any statistically significant reduction of the occurrence of post extraction bacteremia following typical dental extraction.

Keywords: bacteremia, dental extraction, $0.2 \%$ chlorhexidine

\section{INTRODUCTION}

The extraction of teeth is among the most commonly researched manipulation that can produce bacteremia. In healthy individuals the bacteremia is a transitory condition with no clinical presentation and complains. Under certain circumstances it is possible that the bacteremia produces some complications, most notably bacterial endocarditic.

It is well established, that hematogenically disseminated micro flora from the oral cavity is responsible for $10 \%-15 \%$ of bacterial endocarditis' occurrences. Mortality rate of bacterial endocarditic nowadays is still high and varies between 5\% and $11 \%$. [1,2] Several antibiotic regimens are used for prevention of the complications related to post extraction bacteremia. Currently, a trend for reducing the duration of antibiotic prophylaxis can be observed - from 5 days and maximum 21 doses of antibiotic (as suggested in 1955 by the AHA) to a single dose 30-60 minutes prior to the manipulation - with Amoxicillin being antibiotic of choice in various regimen. [3] Alternative methods for controlling the post extraction bacteremia are investigated in an effort to limit the use of antibiotics and therefore 
Preoperative Use of $0.2 \%$ Chlorhexidine Digluconate Mouthwash does not affect the Bacteremia following Closed Dental Extraction

bacterial resistance. In 1977 AHA suggested disinfection of the gingival sulcus prior and in addition to antibiotic prophylaxis of bacterial endocarditic for patients at risk. [4] In 1992 The British Society for Antimicrobial Chemotherapy, BSAC, refined the type and concentration of oral disinfectant Chlorhexidine $-1 \%$ gel for application on the gingival margin, or $0.2 \%$ mouthwash for rinsing the mouth for 5 minutes. [5] In 2006 BSAC recommended single rinsing with $0.2 \%$ Chlorhexidine gluconate prior to dental manipulations that can induce bacteremia in patients at risk of bacterial endocarditic. (6) In contrast, since 2007 AHA refrains from recommending ani antiseptics. [1]

Aim of the study is to investigate the effect of preoperative rinsing with $0.2 \%$ chlorhexidine digluconate on bacteremia following closed dental extraction.

\section{Materials AND Methods}

58 individuals were equally divided in two trial groups - first group did not rinse preoperatively, and the second group did. Inclusion criteria were: clinically healthy patient; single tooth extraction was necessary. Exclusion criteria were: lack of consent, multiple extractions, pharmaceutically controlled chronic conditions, use of antibiotics in the last 6 months, acute oral inflammation, tumors and malignancies, compromised immune system, diabetes mellitus, pregnancy, history of/upcoming radiotherapy to the head and neck region.

Immediately before surgery subjects in the second group rinsed their mouth two times with $10 \mathrm{ml} \quad 0.2 \%$ chlorhexidine digluconate (Parodontax Extra, GlaxoSmithKline, Great Britain) for one minute each. The solution was given in two single-use chemically clean plastic cups. Patients did not rinse with water after that. Tooth extraction was conducted in the following order: 1) local anesthesia; 2) syndesmotomy; 3) luxation and/or rotation of the tooth; 4) traction; 5) revision and inspection of the wound; 6) manual compression; 7) hemostasis.
Several aerobic and anaerobic hemocultures, incubated in an automated system, were utilized for research of bacteriemia (Bact/ALERT, BioMerieux, Inc., Durham, N.C.). The site of venipuncture was disinfected with ethanol, followed by iodine solution. $5 \mathrm{ml}$ of venous blood for each hemoculture (aerobic and anaerobic) was collected from the cubital vein. Then another sterile needle was used to aseptically transfer the material from the syringe into the container which was timely brought to the microbiology laboratory. Three samples of paired hemocultures for aerobic and anaerobic bacteria were acquired accordingly: 1) preoperatively, prior to any manipulations in the mouth; 2) 30 seconds after the extraction was completed; 3) 15 minutes after the extraction was completed. The hemocultures were incubated in BactALERT 3D 60 (BioMerieux, Inc., Durham, N.C.) for 6 days. Positive hemocultures were transferred in solid and liquid nutrient mediums and prepared by Gram stain. Identification of the isolated strains was conducted according to the standard methodsor automatically - using Vitek 2 (BioMerieux, Inc., Durham, N.C.). Some positive hemocultures that showed no bacteria through Gram staining were automatically subcultuvated up to 6 days and were deemed false-positive if no bacterial growth was evident. Hemocultures that were not marked by the device were subjected to routine incubation and transferred to solid nutrient mediums. Evident growth marked them as falsenegative, whereas true-negative hemocultures showed no growth whatsoever.

This study received funding in Project №HO09/ 2018of Medical university of Plovdiv.

\section{RESUltS}

Out of all 58 patients, 29 were males and 29 were females. Average age in the first group was 40.76 with standard deviation of 3.63 , and in the second group it was 48.17 years with standard deviation of 4.13. We failed to establish any statistically significant difference in age between both groups $(\mathrm{p}=0.183)$. Distribution of the extracted teeth in both groups follows in table1.

Table1: Distribution of the extracted teeth according to type

\begin{tabular}{|l|l|l|l|l|l|l|l|l|l|l|}
\hline \multirow{2}{*}{ ToothTrial } & \multicolumn{2}{c|}{ Molars } & \multicolumn{2}{c|}{ Premolars } & \multicolumn{2}{c|}{ Canines } & \multicolumn{3}{c|}{ Incisors } & \multicolumn{2}{c|}{ All } \\
\cline { 2 - 11 } & № & $\%$ & № & $\%$ & № & $\%$ & № & \% & № & $\%$ \\
\hline $1^{\text {st }}$ group (no rinsing) & 24 & 41.38 & 1 & 1.72 & 2 & 3.45 & 2 & 3.45 & 29 & 50 \\
\hline $2^{\text {nd }}$ group (rinsing) & 16 & 27.59 & 7 & 12.07 & 1 & 1.72 & 5 & 8.62 & 29 & 50 \\
\hline All & 40 & 68.97 & 8 & 13.79 & 3 & 5.17 & 7 & 12.07 & 58 & 100 \\
\hline
\end{tabular}


Preoperative bacteremia was confirmed in 7 $(12.07 \%)$ patients - four from the $1^{\text {st }}$ group and 3 from the $2^{\text {nd }}$ group. At the 30th second after completing the extraction bacteremia was evident in 6 patients $(20.69 \%)$ from the first group and $8(27.59 \%)$ from the $2^{\text {nd }}$. Samples at the $15^{\text {th }}$ minute after the extraction revealed 3 subjects $(10.34 \%)$ with bacteremia from both study groups. We failed to recognized any statistically sound difference in occurrence of bacteremia between subjects in both groups at $30^{\text {th }}$ second $(\mathrm{p}=0.548)$ and $15^{\text {th }}$ minute $(\mathrm{p}>0.005)$ after the extraction. The most common finding preoperatively was Coagulase negative Staphylococcus- in $71.43 \%$ of the positive aerobic and in $28.57 \%$ of the positive anaerobic hemocultures. Its presence in both is explained with its facultative anaerobic nature, which allows it to benefit from both respiration and fermentative metabolism. At the $30^{\text {th }}$ second mark after completing the extraction in the first group most common bacteria incubated from aerobic hemocultures was Streptococcus milleri (33.33\%), and Streptococcus viridians (25\%) from the anaerobic ones. In the second group the most common finding was Streptococcus viridians $-50 \%$ of the positive aerobic and $37.5 \%$ of the positive anaerobic hemocultures. The Coagulase negative staphylococcus was most commonly cultivated from the samples at the $15^{\text {th }}$ minute mark $-33.33 \%$ of all positive hemocultures in the first group and $66.67 \%$ of the positive aerobic hemocultures and $33.33 \%$ of the positive anaerobic hemocultures in the second study group. Register of the cultivated bacteria is presented in table 2 .

Table2: Isolated microorganisms after incubating the hemocultures

\begin{tabular}{|c|c|c|c|c|c|c|}
\hline & \multicolumn{3}{|c|}{ First group } & \multicolumn{3}{|c|}{ Second group } \\
\hline & $\mathrm{n}$ & $\begin{array}{l}\text { Isolated from aerobic } \\
\text { hemoculture }\end{array}$ & $\begin{array}{ll}\text { Isolated } & \text { from } \\
\text { anaerobic } & \\
\text { hemoculture } & \\
\end{array}$ & $\mathrm{n}$ & $\begin{array}{ll}\text { Isolated } & \text { from } \\
\text { aerobic } & \\
\text { hemoculture } & \end{array}$ & $\begin{array}{ll}\text { Isolated } & \text { from } \\
\text { anaerobic } & \\
\text { hemoculture } & \end{array}$ \\
\hline $\begin{array}{l}\text { Pre } \\
\text { operat } \\
\text { ivelly }\end{array}$ & 5 & $\begin{array}{l}\text { Coagulase negative } \\
\text { Staphylococcus }\end{array}$ & $\begin{array}{l}\text { Coagulase negative } \\
\text { Staphylococcus; } \\
\text { Streptococcus } \\
\text { mitis/oralis }\end{array}$ & 3 & $\begin{array}{l}\text { Coagulase } \\
\text { negative } \\
\text { Staphylococcus } \\
\text { Staphylococcus } \\
\text { aureus }\end{array}$ & $\begin{array}{l}\text { Coagulase } \\
\text { negative } \\
\text { Staphylococcus } \\
\text { Streptococcus } \\
\text { mitis/oralis }\end{array}$ \\
\hline $\begin{array}{l}\text { At } \\
30^{\text {th }} \\
\text { secon } \\
\text { d } \\
\text { mark }\end{array}$ & 6 & $\begin{array}{l}\text { Streptococcus viridans; } \\
\text { Coagulase negative } \\
\text { Staphylococcus; } \\
\text { Streptococcus milleri; } \\
\text { Streptococcus } \\
\text { constelatus }\end{array}$ & $\begin{array}{l}\text { Streptococcus } \\
\text { viridans; } \\
\text { Streptococcus mitis; } \\
\text { Streptococcus } \\
\text { milleri }\end{array}$ & 8 & $\begin{array}{l}\text { Streptococcus } \\
\text { viridans; } \\
\text { Coagulase negative } \\
\text { Staphylococcus; } \\
\text { Streptococcus } \\
\text { milleri }\end{array}$ & $\begin{array}{l}\text { Coagulase negative } \\
\text { Staphylococcus; } \\
\text { Streptococcus } \\
\text { viridans; } \\
\text { Streptococcus } \\
\text { milleri }\end{array}$ \\
\hline $\begin{array}{l}\text { At } 15^{\text {th }} \\
\text { minute } \\
\text { mark }\end{array}$ & 3 & $\begin{array}{l}\text { Coagulase negative } \\
\text { Staphylococcus; } \\
\text { Streptococcus viridans }\end{array}$ & $\begin{array}{l}\text { Coagulase negative } \\
\text { Staphylococcus; } \\
\text { Bacillus species }\end{array}$ & 3 & $\begin{array}{l}\text { Coagulase } \\
\text { negative } \\
\text { Staphylococcus }\end{array}$ & $\begin{array}{l}\text { Coagulase } \\
\text { negative } \\
\text { Staphylococcus }\end{array}$ \\
\hline
\end{tabular}

The average duration of the extraction in the first group was $16.24 \mathrm{~min}$ at standard deviation of 2.09, and in the second group it was 15.24 min at standard deviation of 2.27. No statistically evident difference between two groups was observed $(\mathrm{p}=0.757)$. We established that the post extraction bacteremia is unaffected by the duration of closed extraction at 30th second mark $(\mathrm{p}=0.289)$, at 15 th minute mark $(\mathrm{p}=0.394)$, as well as the type of extracted tooth $(\mathrm{p}=0.241$ at 30 th second, $\mathrm{p}=0.869$ at 15 th second).

\section{DISCUSSION}

Conflicting evidence about the effect of chlorhexidine prior to dental extraction is preset in the literature. Some authors found that rinsing with $0.2 \%$ chlorhexidine prior to extraction reduces the bacteremia significantly. Barbosaet al. [7] compared the effect of preoperative rinsing with $0.2 \%$ chlorhexidine digluconate in 50 subjects with 52 other patients who did not rinse. Blood samples were acquired 30 seconds and 15 minutes after concluding the extraction. They reported no statistical difference in the occurrence of bacteriemia between both groups at 30th second mark - 50\% versus 52\%, however definite difference was observed at the 15 th minute mark $-4 \%$ versus $23 \%$.

Ugwumba et al. [8] confirmed that preoperative rinsing with $0.2 \%$ chlorhexidine digluconate reduces the post extraction bacteremia after closed tooth extraction. Their study included 101 subjects, divided in two groups. Samples for hem cultures were collected at 1st and 15th minute after extraction. They found that the occurrence of bacteremia in the control group was $52.4 \%$ and in the patients who used the mouthwash it was only $27.1 \%$ ( $\mathrm{p}=0.012$ ). Most 
Preoperative Use of $0.2 \%$ Chlorhexidine Digluconate Mouthwash does not affect the Bacteremia following Closed Dental Extraction

commonly cultivated bacteria were Staphylococcus aureus, Actinomycetes naesulendi, Prevotella, Streptococcu sspp. And Acinetobacter iwoffii. Results of Tomás et al. [9] demonstrate that preoperative application of chlorhexidine convincingly reduces occurrence of post extraction bacteremia - 96\% versus $79 \%$ at 30th second and $64 \%$ versus $30 \%$ at 15 th minute. Other authors confirmed our findings and did not recognize the effect of $0.2 \%$ chlorhexidine on the occurrence of bacteremia following closed dental extraction. Maharajet al. [10] reported no statistically significant difference in the occurrence of bacteremia between patients who rinsed preoperatively with $0.2 \%$ chlorhexidine digluconate and the control group who did not $-40 \%$ versus $35 \%$. Similar results announced Lockhart [11], who conducted randomized, double-blinded, placebo-controlled study on 70 subjects. Hem cultures were positive in $94 \%$ of the control patients and in $84 \%$ of patients who rinsed with chlorhexidine, with no evidence statistically significant difference.

\section{CONClusion}

Data from the conducted study demonstrated that preoperative rinsing with $0.2 \%$ chlorhexidine digluconate has no statistically meaningful effect on reduction of bacteremia following closed extraction of a single tooth.

\section{REFERENCES}

[1] Wilson W, Taubert KA, Gewitz M, et al. Prevention of infective endocarditis: guidelines from the American Heart Association. A guideline from the American Heart Association Rheumatic Fever, Endocarditis and Kawasaki Disease Committee, Council on Cardiovascular Disease in the Young, and the Council on Clinical Cardiology, Council on Cardiovascular Surgery and Anesthesia and the Quality of Care and Outcomes Research Interdisciplinary Working Group. J Am Dent Assoc 2007; 138: 739-745, 747-760.
[2] Carmona IT, Diz Dios P, Scully C. An update on the controversies in bacterial endocarditis of oral origin. Oral Surg Oral Med Oral Pathol Oral Radiol Endod 2002; 93: 660-670.

[3] Poveda Roda R, Jiménez Y, Carbonell E, Gavaldá C, Margaix Muñoz M, Sarrión Pérez G. Bacteremia originating in the oral cavity. A review. Med Oral Patol Oral Cir Bucal. 2008;13(6):E355-62.

[4] Kaplan EL. Prevention of bacterial endocarditis. Circulation 1977;56: 139A-143 A.

[5] Simmons NA, Ball AP, Cawson RA, Eykyn SJ, Littler WA, McGowan DA, et al. Antibiotic prophylaxis and infective endocarditis. Lancet 1992;339: 1292-1293.

[6] Gould FK, Elliott TS, Foweraker J, Fulford M, Perry JD, Roberts GJ, et al. Guidelines for the prevention of endocarditis: report of the Working Party of the British Society for Antimicrobial Chemotherapy. J Antimicrob Chemother. 2006; 57: 1035-1042.

[7] Barbosa M, Prada-López I, Álvarez M, Amaral B, de los Angeles CD, Tomás I. Post-tooth extraction bacteraemia: a randomized clinical trial on the efficacy of chlorhexidine prophylaxis. PLoS One. 2015. May 8;10(5):e01 24249

[8] Ugwumba CU, Adeyemo WL, Odeniyi OM, Arotiba GT, Ogunsola FT. Preoperative administration of $0.2 \%$ chlorhexidine mouthrinse reduces the risk of bacteremia associated with intra-alveolar tooth extraction. J Craniomaxillofac Surg. 2014;42(8):1783-8.

[9] Tomás I, Alvarez M, Limeres J. et al. Effect of a chlorhexidine mouthwash on the risk of postextraction bacteremia. Infect Control Hosp Epidemiol. 2007;28:577-582.

[10] Maharaj B, Coovadia Y, Vayej AC. A comparative study of amoxicillin, clindamycin and chlorhexidine in the prevention of postextraction bacteraemia. Cardiovasc J Afr. 2012; 23: 491-494.

[11] Lockhart PB. An analysis of bacteremias during dental extractions. A double-blind, placebocontrolled study of chlorhexidine. Arch Intern Med. 1996;156:513-520.

Citation: Galina Gavazova, Petia Pechalova, Preoperative Use of $0.2 \%$ Chlorhexidine Digluconate Mouthwash does not affect the Bacteremia following Closed Dental Extraction. ARC Journal of Surgery.2019; 5(4):13-16. DOI: http://dx.doi.org/10.20431/2455-572X.0504003

Copyright:(C) 2019 Authors. This is an open-access article distributed under the terms of the Creative Commons Attribution License, which permits unrestricted use, distribution, and reproduction in any medium, provided the original author and source are credited. 